\title{
Simultaneous Determination of Ethanol and Carbon Dioxide by Two-Order Microdiffusion Analysis and Its Application to Analysis of Alcoholic Fermentation1)
}

\author{
Hideko IshiHaRa and OTOHARU IshizaKa \\ Faculty of Pharmaceutical Sciences, Nagoya City University2)
}

(Received February 12, 1971)

\begin{abstract}
A procedure and an apparatus of two-order microdiffusion analysis have been devised and applied to the simultaneous determination of ethanol and carbon dioxide. The conditions and the limitation of the assay method are as follows:

1. Amount of outer chamber solution; $3 \mathrm{ml}$

2. $\mathrm{pH}$ of outer chamber solution; $1.3-8.7$

3. Range of determination and value of coefficient of variation; ethanol, less than $23 \mathrm{mg}, 2 \%$ carbon dioxide, less than $14 \mathrm{mg}$, less than $6 \%$

4. Diffusion temperature; $30-37^{\circ}$

5. Diffusion time; either more than $24 \mathrm{hr}$ at $37^{\circ}$ or $30 \mathrm{hr}$ at $30^{\circ}$

6. Rate of recovery; ethanol, $99 \%$ (pH 1.3), carbon dioxide $100 \%$ (pH 1.3 )

The assay method was also applied to simultaneous determination of ethanol and carbon dioxide evolved in the process of alcoholic fermentation.
\end{abstract}

The microdiffusion analysis was established by Conway and his coworkers ${ }^{3)}$ and, up to this time, the method has been used only for the estimation of one component released from a sample solution. However, in chemical or biochemical reactions, there often exist more than two volatile components in the reaction media. Such situation imposes some restrictions on the applicability of this method. Therefore, it is desirable to be able to estimate simultaneously more than two volatile components using only one unit operation. From this standpoint, the authors devised a novel microdiffusional procedure by which more than two volatile components can be simultaneously estimated. We applied this procedure to a simultaneous determination of carbon dioxide and ethanol, both of which are products of alcoholic fermentation. Using this technique, we also investigated the effect of dyes on the rate of the fermentation. The purpose of the investigation was to check the dye which inhibit alcoholic fermentation. In the new procedure the conventional methods for the determination of ethanol and carbon dioxide were somewhat modified. To the colorimetric determination of ethanol, we applied Ozawa's modified procedures ${ }^{4}$ of Conway's method with further improvement. Among several simplified methods for the determination of carbon dioxide, we selected Kawabata's chelate-titration method, $\left.{ }^{5}\right)$ and used it with some modifications. This selection is based on the fact that the interference of volatile organic acids formed during fermentation can be excluded.

\section{Experimental}

Apparatus-Conway-Ishizaka's semi-micro unit (the outer chamber: inner diameter $90 \mathrm{~mm}$, inner height $17 \mathrm{~mm}$; the inner chamber: outer diameter $65 \mathrm{~mm}$, inner diameter $60 \mathrm{~mm}$, inner height $8.5 \mathrm{~mm}$ ),

1) The work was presented at the Meeting of Tokai Branch, Pharmaceutical Society of Japan, Nagoya, Feb. 1967 and a part of this work was presented as a preliminary communication; H. Ishihara and O. Ishizaka, Chem. Pharm. Bull. (Tokyo), 16, 2524 (1968).

2) Location: Tanabe-dori, Mizuho-ku, Nagoya.

3) E.J. Conway, "Microdiffusion Analysis \& Volumetric Error," Crosby Lockwood \& Son Ltd., 1962.

4) M. Ozawa, T. Nagaoka, and K. Kakuno, Eisei Kagaku, 10, 17 (1964).

5) M. Kawabata, H. Mochizuki, R. Kajiyama, M. Watanabe, M. Ishii, and K. Sasaki, Bunseki Kagaku, 11, 192 (1962). 
purchased from Shibata Chemical Apparatus MFG. Co., Ltd. is used with special accessory cups. The inner chamber contains two large cups for absorbents (inner diameter $22.3 \mathrm{~mm}$, inner height $12 \mathrm{~mm}$ ), and if necessary, an additional large cup or a small cup (inner diameter $12.5 \mathrm{~mm}$, inner height $12 \mathrm{~mm}$ ) is inserted in it: when test solution is less than $2 \mathrm{ml}$ the test solution is inoculated, not into the outer chamber but into the third cup mentioned above, because the volume of the test solution decreases considerably owing to the strong desiccative effect of the acidic absorbent. The apparatus is shown in Fig. 1.

Reagents-1) $0.01 \mathrm{~m}$ EDTA-Mg Soln.: $7.5 \mathrm{~g}$ of disodium ethylenediaminetetraacetate was dissolved in $800 \mathrm{ml}$ of $\mathrm{H}_{2} \mathrm{O}$, and the solution was adjusted to $\mathrm{pH} 7.0$ with $1 \mathrm{~N} \mathrm{NaOH} .2 .1 \mathrm{~g}$ of $\mathrm{MgCl}_{2}$ was added to the solution and the solution was diluted to 1 liter with $\mathrm{H}_{2} \mathrm{O}$. The soln. was standardized against $0.01 \mathrm{M} \mathrm{MgCl}_{2}$ standard soln.

2) $0.01 \mathrm{M} \mathrm{MgCl}_{2}$ Standard Soln.: To a suspension of $0.4032 \mathrm{~g}$ of $\mathrm{MgO}$, previously dried, in $10 \mathrm{ml}$ of $\mathrm{H}_{2} \mathrm{O}$ was added dil. $\mathrm{HCl}$ to make a soln. Excess $\mathrm{HCl}$ and $\mathrm{H}_{2} \mathrm{O}$ were evaporated to dryness on a water bath and the residue was dissolved in $\mathrm{H}_{2} \mathrm{O}$, the final volume being 1 liter.

3) Ammonia Buffer Soln.: $67.5 \mathrm{~g}$ of $\mathrm{NH}_{4} \mathrm{Cl}$ was added to $570 \mathrm{ml}$ of aq. $\mathrm{NH}_{4} \mathrm{OH}(28 \%)$, and the solution was diluted to 1 liter with $\mathrm{H}_{2} \mathrm{O}$.

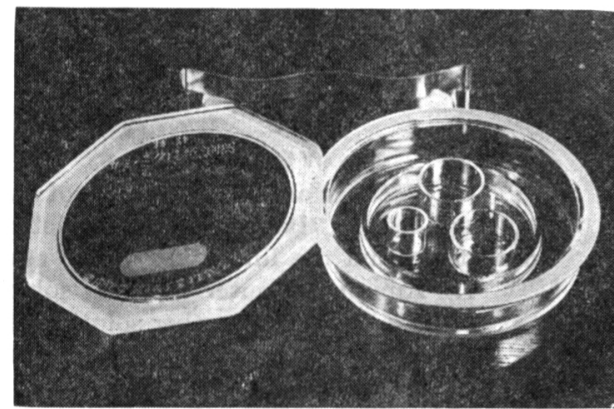

Fig. 1. Apparatus of Two-Order Microdiffusion Analysis

4) Indicator Soln.: $0.5 \mathrm{~g}$ of Eriochrome Black $\mathrm{T}$ and $4.5 \mathrm{~g}$ of hydroxylamine- $\mathrm{HCl}$ were dissolved in 100 $\mathrm{ml}$ of $\mathrm{MeOH}$.

5) $0.03 \mathrm{M} \mathrm{BaCl}_{2}$ Soln. : $7.32 \mathrm{~g}$ of $\mathrm{BaCl}_{2} \cdot 2 \mathrm{H}_{2} \mathrm{O}$ was dissolved in $\mathrm{CO}_{2}$-free $\mathrm{H}_{2} \mathrm{O}$, and the solution was made up to 1 liter.

6) $2 \mathrm{~N} \mathrm{~K} \mathrm{Cr}_{2} \mathrm{O}_{7}-\mathrm{H}_{2} \mathrm{SO}_{4}$ Soln.: $9.808 \mathrm{~g}$ of $\mathrm{K}_{2} \mathrm{Cr}_{2} \mathrm{O}_{7}$ was dissolved in $10 \mathrm{~N} \mathrm{H}_{2} \mathrm{SO}_{4}$, and the solution was made up to $100 \mathrm{ml}$ with $10 \mathrm{~N}_{2} \mathrm{SO}_{4}$.

7) Henneberg's Culture Medium: A mixture of $\left(5 \mathrm{~g}\right.$ of $\mathrm{CaCO}_{3}, 2 \mathrm{~g}$ of $\mathrm{MgSO}_{4} \cdot 7 \mathrm{H}_{2} \mathrm{O}, 5 \mathrm{~g}$ of $\mathrm{KH}_{2} \mathrm{PO}_{4}, 5 \mathrm{~g}$ of peptone and $150 \mathrm{~g}$ of sucrose in 1 liter of $\mathrm{H}_{2} \mathrm{O}$ ) is sterilized in an autoclave. This medium is adopted only for cultivation of yeast strain.

8) Culture Medium for Assay (C.M.A.): Modified Henneberg's medium is adopted; sucrose content is decreased to $0.1 \mathrm{~m}(34.23 \mathrm{~g} /$ liter $)$.

9) Culture Medium for Blank Test (C.M.B.): A medium in which sucrose is omitted from C.M.A. is adopted.

Sake Yeast Strain_-Saccharomyces sake var. the Brewing Institute No. 6 was used throughout this work. It was inoculated on the Henneberg's slant agar-agar culture medium and incubated at $30^{\circ}$ for 4 days.

Preparation of Yeast Cell Suspension_-Pipetted yeast cells at the exponential phase were suspended in sterilized soln. of $0.5 \% \mathrm{KH}_{2} \mathrm{PO}_{4}$ and the suspension was centrifuged at $3000 \mathrm{rpm}$ for 10 min. The procedure was repeated further three times. The precipitated cells were resuspended in $0.5 \% \mathrm{KH}_{2} \mathrm{PO}_{4}$. The volume of the suspension was adjusted so as to give a cell count approximately $5 \times 10^{7}$ per ml. Count of yeast was measured by Thoma's blood cell counter. The suspension was assayed, after one day's standing at room temperature.

Procedure-1. General Manipulation and Diffusion: One $\mathrm{ml}$ of test soln. (or solvent for blank

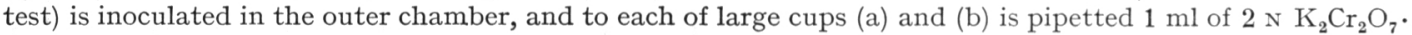
$\mathrm{H}_{2} \mathrm{SO}_{4}$ and $1 \mathrm{ml}$ of $1 \mathrm{~N} \mathrm{KOH}$ soln., respectively. Then $2 \mathrm{ml}$ of $0.1 \mathrm{~N} \mathrm{H}_{2} \mathrm{SO}_{4}$ is introduced into the outer chamber as a releasing agent through a pipet. The unit is covered immediately with a lid smeared with liquid paraffine, closed airtightly with a steel spring clip, and left standing at $30-37^{\circ}$. After the lapse of time the lid is detached from the unit and the contents are assayed.

2. Determination of Carbon Dioxide: The large cup (b) is transferred into a beaker of $100 \mathrm{ml}$ contents. Ten $\mathrm{ml}$ of $0.03 \mathrm{M} \mathrm{BaCl}_{2}, 10 \mathrm{ml}$ of ammonia buffer, $30 \mathrm{ml}$ of $\mathrm{MeOH}$ and 5 drops of indicator soln. are added successively as fast as possible. When test soln. contain more than $12 \mathrm{mg}$ of carbon dioxide, $15 \mathrm{ml}$ of $0.03 \mathrm{M} \mathrm{BaCl}_{2}$ is added. The cup is taken out from the beaker, washed with a small amount of $\mathrm{H}_{2} \mathrm{O}$, and the washings combined with the contents of the beaker. The combined contents are titrated with $0.01 \mathrm{M}$ EDTA-Mg standard soln. under continuous stirring. Blank unit is treated simultaneously as mentioned above.

$\mathrm{CO}_{2} \mathrm{mg} /$ outer chamber soln. $=(B-A) \times 0.44 \times f$

$B: \mathrm{ml}$ of titration for blank unit

$A: \mathrm{ml}$ of titration for assay unit

$f$ : factor of $0.01 \mathrm{M}$ EDTA-Mg soln. 
3. Determination of Ethanol: The contents of large cup (a) is transferred into a measuring flask of $10 \mathrm{ml}$ contents with an aid of $\mathrm{H}_{2} \mathrm{O}$, and made up to $10 \mathrm{ml}$ with addition of $\mathrm{H}_{2} \mathrm{O}$. The optical absorbance is checked under the comparison with blank test soln., and ethanol concentration calculated from the calibration curve.

4. Assay of Alcoholic Fermentation: The manipulation is performed as fast and aseptically as possible, following the steps ( $c f$. procedure 1) as mentioned below.

1) One $\mathrm{ml}$ of $2 \mathrm{~N} \mathrm{~K}_{2} \mathrm{Cr}_{2} \mathrm{O}_{7}-\mathrm{H}_{2} \mathrm{SO}_{4}$ is pipetted into a large cup (a).

2) Each $0.5 \mathrm{ml}$ of C.M.A. or C.M.B. is settled into a small cup through Ostwald's pipet, the former adapts for test soln. and the latter for blank test.

3) One $\mathrm{ml}$ of $1 \mathrm{~N} \mathrm{KOH}$ is inoculated into a large cup (b) through Bang burette, $2 \mathrm{ml}$ contents. This procedure is omitted when the assay is aimed at ethanol contents determination only.

4) Yeast cell suspension $(0.5 \mathrm{ml})$ is inoculated into a small cup through Ostwald's pipet and the unit is manipulated under the direction described in procedure 1 . at $30^{\circ}$ for the period of more than $30 \mathrm{hr}$. After the lapse of time, the large cups (a) and (b) are taken out from the inner chamber of the unit and the contents analysed.

At any intermediate stage of fermentation, addition of $0.2 \mathrm{ml}$ of $18 \%$ trichloroacetic acid into the small cup through a slit stops fermentation only, while diffusion of carbon dioxide and ethanol is continued as usual. Slit formation is performed by horizontal moving of a lid under a caution that the manipulation should be done as fast as possible.

\section{Result}

\section{Range of Assay}

One $\mathrm{ml}$ of $2 \mathrm{~N} \mathrm{~K}_{2} \mathrm{Cr}_{2} \mathrm{O}_{7}-\mathrm{H}_{2} \mathrm{SO}_{4}$ was sufficient to oxidize $0-23 \mathrm{mg}$ of ethanol as indicated in Fig. 2. On the other hand, it was apparent from the result of recovery of carbon dioxide shown in Table I that the carbon dioxide must be less than $14 \mathrm{mg}$ for an accurate measurement.

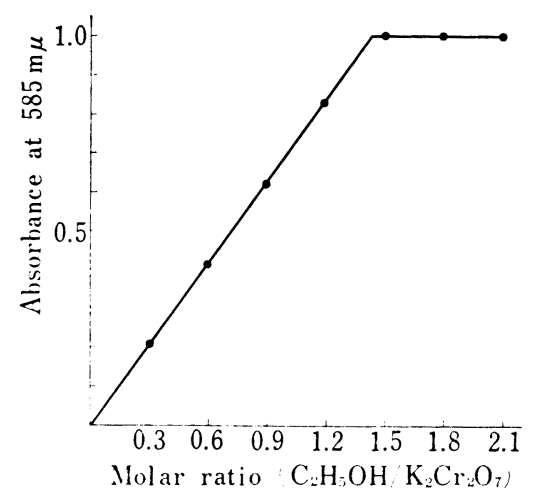

Fig. 2. Stoichiometry of the Oxidation of Ethanol

One $\mathrm{ml}$ of $2 \mathrm{~N} \mathrm{~K}_{2} \mathrm{Cr}_{2} \mathrm{O}_{7}-\mathrm{H}_{2} \mathrm{SO}_{4}$ and $0.1-0.7 \mathrm{ml}$ of $1 \mathrm{M}$ $\mathrm{C}_{2} \mathrm{H}_{5} \mathrm{OH}$ were pipetted into a measuring flask of $10 \mathrm{ml}$ volume, mixed and left standing at $30^{\circ}$ for $120 \mathrm{~min}$, then made up to $10 \mathrm{ml}$ with $\mathrm{H}_{2} \mathrm{O}$ and optical absorbance was measured against $2 \mathrm{NK}_{2} \mathrm{Cr}_{2} \mathrm{O}_{7}-\mathrm{H}_{2} \mathrm{SO}_{4}$ diluted into 10 -fold with $\mathrm{H}_{2} \mathrm{O}$.

\section{Deviation and Recovery}

The coefficient of variation and recovery in each standard series are described in Table I.

\section{Consideration of Diffusion $\mathbf{p H}$}

As shown in Fig. 3, ethanol and carbon dioxide were almost completely recovered from a mixture of test and buffer solution at the range of $\mathrm{pH} 1.3-8.7$

\section{Effect of Diffusion Temperature}

As shown in Fig. 4, diffusion completed at $30^{\circ}$ after $30 \mathrm{hr}$ or at $37^{\circ}$ after $24 \mathrm{hr}$.

5. Relationship Between Yeast Cell Numbers and Fermentation Activities

Fermentation activities of yeast, inoculated in C.M.A. without or with $0.1 \%$ Rose Bengale, were investigated with preliminary examinations. As shown in Fig. 5 (1), without Rose Bengale, maximum fermentation was attained starting with the cells more than $1 \times 10^{7}$, while in the presence of the dye it required more than $2 \times 10^{7}$ starting cells to attain the same fermentation (Fig. $5(2)$ ). In both cases the fermentation was markedly decreased or inhibited if the count diminished from the indicated values.

\section{Fermentation Rate as a Function of Time}

As shown in Fig. 6, the fermentation appeared to finish within $6 \mathrm{hr}$. As already described in 4, complete diffusion of ethanol and carbon dioxide required at least $30 \mathrm{hr}$ at $30^{\circ}$.

6) The absorbance was determined on a Hitachi Parkin-Elmer Spectrophotometer Model 139. 
TABLE I. Deviation and Recovery

\begin{tabular}{ccccr}
\hline \hline $0.4 \mathrm{M} \mathrm{KHCO}_{3}(\mathrm{ml})$ & $\left.\mathrm{CO}_{2}(\mathrm{mg})^{a}\right)$ & $\bar{X}(\mathrm{ml})$ & $\sigma / \bar{X} 100$ & Recovery \% \\
\hline 0.1 & 1.76 & 3.07 & 6.0 & 92.5 \\
0.2 & 3.52 & 8.03 & 3.3 & 100.3 \\
0.3 & 5.28 & 10.97 & 1.4 & 91.5 \\
0.4 & 7.04 & 16.10 & 1.3 & 100.6 \\
0.5 & 8.80 & 19.69 & 0.35 & 98.4 \\
0.6 & 10.56 & 24.40 & 0.29 & 101.7 \\
0.7 & 12.32 & 28.20 & 0.56 & 100.7 \\
0.8 & 14.08 & 31.70 & 1.2 & 99.1 \\
0.9 & 15.84 & 33.50 & 1.6 & 93.1 \\
1.0 & 17.60 & 36.60 & 0.85 & 91.5 \\
\hline
\end{tabular}

\begin{tabular}{ccccc}
\hline $0.4 \mathrm{M} \mathrm{C}_{2} \mathrm{H}_{5} \mathrm{OH}(\mathrm{ml})$ & $\mathrm{C}_{2} \mathrm{H}_{5} \mathrm{OH}(\mathrm{mg})^{a)}$ & $\bar{X}\left(\mathrm{OD}_{585}\right)$ & $\sigma / \bar{X} 100$ & Recovery \% \\
\hline 0.1 & 1.84 & 0.086 & 1.8 & 108.1 \\
0.2 & 3.68 & 0.162 & 1.1 & 101.9 \\
0.4 & 7.36 & 0.325 & 2.0 & 102.0 \\
0.6 & 11.04 & 0.506 & 0.89 & 101.2 \\
0.8 & 14.72 & 0.672 & 1.6 & 103.4 \\
1.0 & 18.40 & 0.832 & 1.1 & 104.0 \\
\hline
\end{tabular}

$\boldsymbol{X}$ : average of titer or absorbance $\boldsymbol{\sigma}:$ standard deviation a) theoretical

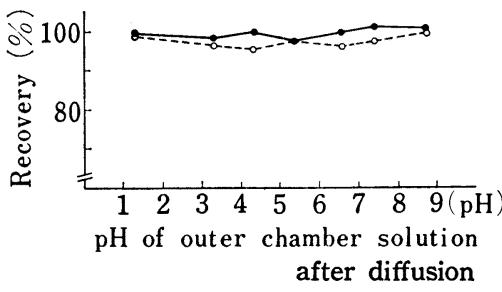

Fig. 3. Effect of $\mathrm{pH}$ on Simultaneous Recovery of $\mathrm{C}_{2} \mathrm{H}_{5} \mathrm{OH}$ and $\mathrm{CO}_{2}$

Outer chamber solution contained $0.1 \mathrm{ml}$ of $0.4 \mathrm{M}$ $\mathrm{KHCO}_{3}, 0.1 \mathrm{ml}$ of $0.4 \mathrm{M} \mathrm{C}_{2} \mathrm{H}_{5} \mathrm{OH}, 0.8 \mathrm{ml}$ of $\mathrm{H}_{8} \mathrm{O}$ and $2 \mathrm{ml}$ of buffer. From $\mathrm{pH} 3.3$ to 8.7 , the buffer was $0.2 \mathrm{M} \mathrm{Na}_{2} \mathrm{HPO}_{4}-0.1 \mathrm{M}$ citrate. At $\mathrm{pH} 1.3,0.1 \mathrm{~N} \mathrm{H}_{2} \mathrm{SO}_{4}$ was used.

--O--: $\mathrm{C}_{2} \mathrm{H}_{5} \mathrm{OH} \longrightarrow$ - $\mathrm{CO}_{2}$

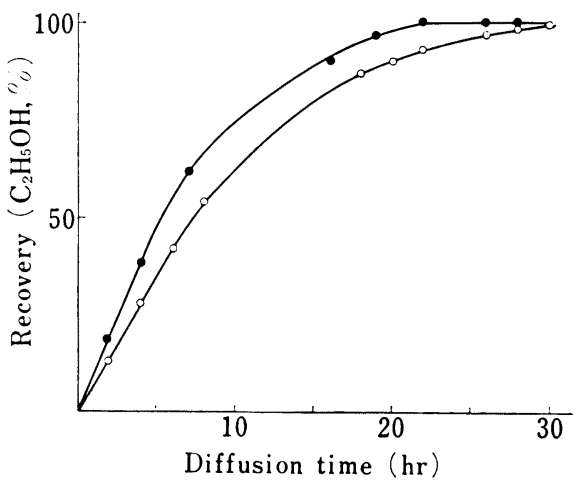

Fig. 4. Effect of Diffusion Time and Temperature on Recovery

A mixture of $0.5 \mathrm{ml}$ of $0.4 \mathrm{M} \mathrm{KHCO}_{3}, 0.5 \mathrm{ml}$ of $0.4 \mathrm{M}$ $\mathrm{C}_{2} \mathrm{H}_{6} \mathrm{OH}$ and $2 \mathrm{ml}$ of $0.1 \mathrm{~N}_{2} \mathrm{HO}_{4}$ were treated at $30^{\circ}$ and $37^{\circ}$ for the period of $2-30 \mathrm{hr}$.

- - - diffused at $30^{\circ}$

-: diffused at $37^{\circ}$

Therefore, the total incubation period was $36 \mathrm{hr}$. From the experimental data obtained, it. was impossible to determine the order of production of carbon dioxide and ethanol.

\section{Rate of Fermentation Under Addition of Dyes}

Eight synthetic dyes were selected and investigated for their effect on fermentation. From the results shown in Table II, Phloxine and Rose Bengale remarkably inhibited the fermentation and the extents of the inhibition were $37 \%$ and $59 \%$, respectively. 


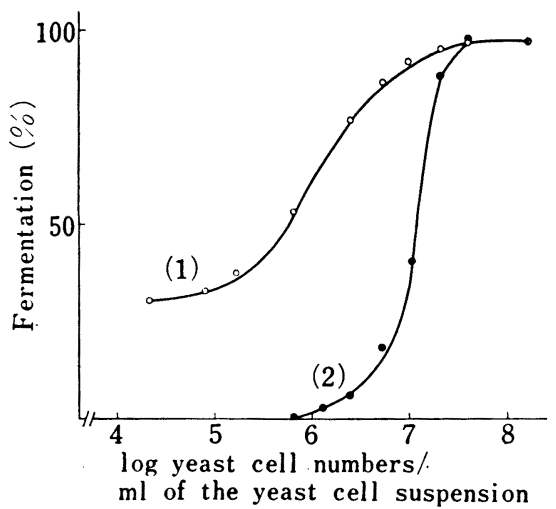

Fig. 5. Effect of Yeast Cell Numbers on the Fermentation

Into $0.5 \mathrm{ml}$ of C.M.A. soln., $0.5 \mathrm{ml}$ of the yeast cell suspension (ca. $10^{4}-10^{\circ}$ cells per $\mathrm{ml}$ ) was inoculated and incubated at $30^{\circ}$ for $40 \mathrm{hr}$.

(1) - - : no addition

(2) - : addition of Rose Bengale at the $0.1 \%$

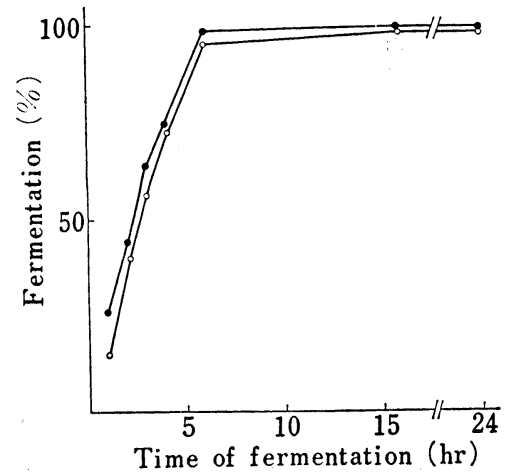

Fig. 6. Fermentation Rate as a Function of Time

At an arbitrary time of fermentation, $0.2 \mathrm{ml}$ of $18 \%$ T.C.A. soln. was added into the small cup to stop the fermentation and the diffusion continued for further $30 \mathrm{hr}$.

-O-: $\mathrm{C}_{2} \mathrm{H}_{5} \mathrm{OH} \mathrm{CO}_{2}$

TABLE II. Influence of Dye on the Fermentation

\begin{tabular}{lc|cr}
\hline \multicolumn{1}{c|}{ Dye $^{a)}$} & $\begin{array}{c}\text { Produced } \\
\mathrm{C}_{2} \mathrm{H}_{5} \mathrm{OH} \%\end{array}$ & Dye & $\begin{array}{c}\text { Produced } \\
\mathrm{C}_{2} \mathrm{H}_{5} \mathrm{OH} \%\end{array}$ \\
\hline Indigo carmine (90.7) & 97.8 & Phloxine (90.2) & 63.0 \\
Tartrazine (93.1) & 95.6 & Rose bengale (91.0) & 41.3 \\
Acid violet (86.6) & 100.0 & Acid red (94.4) & 100.0 \\
Erythrosine (91.3) & 100.0 & Control & 100.0 \\
Eosine (90.1) & 103.2 & & \\
\hline
\end{tabular}

a) Obtained from Sanei Kagaku Co., Tokyo.

( ): purity $\%$

Acknowledgement The authors are greatly indebted to Professor S. Tejima and Assistant Professor H. Ikezawa for their kind encouragement. 